\title{
Socio-Psychological Effects of Urban Green Areas: Case of Kirklareli City Center
}

${ }^{* 1}$ Dr. Ezgi TOK@ , ${ }^{2}$ M.Sc. Merve GÜROĞLU AĞDAŞ®, ${ }^{3}$ M.Sc. Mete Korhan ÖZKÖK@ , ${ }^{4}$ M.Sc. Azem KURU®

1, 2, 3 and 4 Faculty of Architecture, Kirklareli University, Kirklareli, Turkey

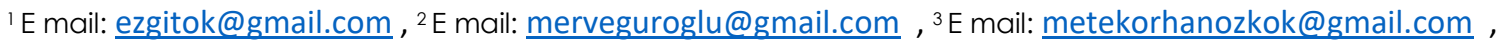

${ }^{4}$ E mail: azemkuru@gmail.com

\section{ARTICLE INFO:}

\section{Article history:}

Received 20 April 2019

Accepted 6 June 2019

Available online 30 August

2019

\section{Keywords:}

Green Spaces;

Socio-Psychological

Effect;

Urban Planning;

Urban Health.

This work is licensed under a

Creative Commons Attribution

NonCommercial - NoDerivs 4.0. "CC-BY-NC-ND"

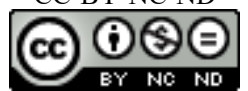

This article is published with Open Access at www.ijcua.com

\begin{abstract}
A B S T R A C T
Urban open green spaces have an important role in today's health problems and the necessity for urban health to create green areas that have high accessibility for all citizens. Acceleration of urbanization in recent decades decays balance of green areas and impervious surfaces in cities because of rent seeking society. The main problem associated with adequate provision of green area and fair access for residents. According to the "Spatial Planning Policy Framework" the green area per capita in urban area $\left(10 \mathrm{~m}^{2}\right)$, Kirklareli doesn't provide green space per capita. The aim of the study is to identify the socio-psychological effects of the green areas in the Kirklareli. The objectives of the study is to determine the correlation between socio-psychological criteria with green space accessibility, per capita and visiting time and to discuss the findings rationale. The following hypothesis was proposed "urban green areas on inhabitants have positive effects on human health, quality of life and stress". In this context, a survey was conducted to analyze the socio-psychological effects of urban green spaces in Kirklareli. The expected outcome of the study is that green areas are associated with positive emotions, green space per capita and accessibility that can assist to decrease inequalities in health.
\end{abstract}

JOURNAL OF CONTEMPORARY URBAN AFFAIRS (2020), 4(1), 47-60. https://doi.org/10.25034/ijcua.2020.v4n1-5

www.ijcua.com

Copyright (0 2019 Journal of Contemporary Urban Affairs. All rights reserved.

\section{Introduction}

Historically, from the beginning of the 20th century, there has been an awareness of the importance of green space in urban planning (Verheij et al., 2008). However, the population growth rates have been increasing exponentially, natural and seminatural areas (agriculture, pasture, forest and urban green areas) are under pressure in urban fringe (Angel MartíNez-GonzÁLez et al., 2001). As a result of this situation, green space per capita and accessibility to urban green space decrease, therefore the presence of open and green areas is needed more than ever before. Due to the adverse effects of the decline in the areal size of urban green space in the urban areas, studies on the effects of green areas on urban health have started to be carried out (Cicea \& PîRlogea, 2011). \footnotetext{
*Corresponding Author:

Faculty of Architecture, Kirklareli University, Kirklareli, Turkey Email address: ezgitok@gmail.com
} 
Today, physical inactivity has become a global health problem that the World Health Organization emphasizes as a risk factor. Although lifestyles vary from region to region, in some countries the rate of inactivity is about $80 \%$. However, regular physical activity is associated with heart disease, diabetes, breast-cancer risk, mental health and quality of life. For that reason, it is vital that all nations should provide the opportunity of safe and accessible environments to be physically active in their daily lives in order to improve their personal and social health to ensure their social, economic and cultural development. In this context, the world health organization has identified the draft global vision for 2018-2030 as "more active people for a healthier world". One of the action plans to achieve this goal has been identified as strengthening the access chances of all individuals of all ages to high quality public and open green areas, recreation areas, sports facilities (World Health Organization, 2018). Urban green areas are considered as the main environment providing opportunities for various physical activities for cities (Koohsari et al., 2015).

In the zoning regulation, green areas are defined as green spaces that include the playpen, playground, resting, walking, picnic and recreational areas, which are reserved for society to benefit (Çevre ve Şehircilik Bakanlı̆ı̆ndan, 2017). The urban green and open areas are designed in a certain hierarchy according to their variety and qualities. These can be listed as; children's playground, small scale neighborhood unit park, neighborhood and urban parks, regional parks and national parks. The neighborhood parks could have children's playgrounds, parks, sports areas and passive green space activities (Ersoy, 2015). Urban open and green areas should be accessible to pedestrians at neighborhood and subscales (Aydemir, 2004; Ersoy, 2015). The areal size should be suitable for their intended use, and they should be ergonomic, safe, aesthetic and accessible to all layers of society, (Aydemir, 2004). The level of physical activity, asphalt roads, playgrounds (Kaczynski et al., 2008), woodland areas, water elements (Kaczynski et al., 2008; Schipperijn et al., 2013), lighting, walking and cycling routes, bicycle parking, beautiful landscape, the size of the green area (Schipperijn et al., 2013), safety (Maas et al., 2009). Studies on the positive effects of open and green areas on individuals gain importance (Angel Martínez-GonzÁLez et al., 2001). The quality of life in cities mostly depends on the availability of attractive and accessible green areas. There is a common consensus on the necessity of urban green areas for the health and happiness of individuals (Cicea \& PîRlogea, 2011).
Green area and health have a positive relationship (Ersoy, 2015; Maas et al., 2009). Studies have pointed out that the relation between green areas and human health affects the quality of life and stress-reduction. The use of green areas contributes positively to coping with stress and green areas play a key role in designing healthy environments in cities. In the last thirty years, it has been exposed that the healing effect of urban green areas has been found in terms of public health and it has been observed that there is a positive correlation to decline stress and mental exhaustion between how often individuals use green areas and how much time they spend in green areas (Grahn \& Stigsdotter, 2003; Nielsen \& Hansen, 2007; Stigsdotter et al., 2010).

In general, the benefits of green areas;

Socially; provides social interaction (Aydemir, 2004; Cicea \& PîRlogea, 2011; Ersoy, 2015; Maas et al., 2009; Oktay, 1998; Verheij et al., 2008), opportunity to meet with nature (Kremer et al., 2016), physical activity (Verheij et al., 2008), promotes public health (Cicea \& PîRlogea, 2011; Ersoy, 2015), stress-reducement (Cicea \& PîRlogea, 2011; Ersoy, 2015; Honold et al., 2015; Kaplan, 2001; Verheij et al., 2008), prevents from depression (Bratman et al., 2015), helps to get rid of fatigue (Verheij et al., 2008), aesthetic to the built environment (Aydemir, 2004; Cicea \& PîRlogea, 2011), activities for recreation and entertainment and the chance to escape the city life (Aydemir, 2004).

Moreover, it has many ecological benefits. These benefits include oxygen production, dust and bacteriological treatment of the atmosphere (Cicea \& PîRlogea, 2011; Ersoy, 2015), reduction of gases causing air pollution (Ersoy, 2015), shading areas, noise reduction (Cicea \& PîRlogea, 2011), climatic control (Aydemir, 2004; Cicea \& PîRlogea, 2011; Oktay, 1998; Shishegar, 2014), preservation and maintenance of local vegetation (Aydemir, 2004; Cicea \& PîRlogea, 2011; Oktay, 1998), and regulation of ecosystem services (Roberts et al., 2018; Shishegar, 2014).

Green areas add economic identity to the city (Aydemir, 2004; Cicea \& PîRlogea, 2011), attracts investment, increases the value of urban space and housing (Cicea \& PîRlogea, 2011), makes positive contributions such as attracting tourists (Aydemir, 2004; Cicea \& PîRlogea, 2011). The interaction between man and nature is beneficial for the health and happiness of individuals (Fuller \& Gaston, 2009; Roberts et al., 2018). Being in natural environments positively affects blood pressure, cholesterol and stress reduction, and has a positive specific relationship with mental health and cardiovascular diseases (Bedimo-Rung et al., 2005). Interaction with nature can take place by watching a natural landscape or by being in a natural environment (Huynh et al., 2013). Urban 
green areas in cities have many benefits in terms of health (Alcock et al., 2014; Fuller \& Gaston, 2009; Lee \& Maheswaran, 2011; Roberts et al., 2018; Soga \& Gaston, 2016) and well-being (Fuller \& Gaston, 2009; Roberts et al., 2018; Soga \& Gaston, 2016), and it is found that living in a close proximity to the green area has a reducing effect on the heart and respiratory diseases (Tamosiunas et al., 2014; Villeneuve et al., 2012) and there is a positive relationship between the higher level of physical activity (Cohen et al., 2007; Toftager et al., 2011) and the frequency of green areas usage (Akpinar, 2014; Cohen et al., 2007; Nielsen \& Hansen, 2007). The potential benefits from open green areas are becoming vital in cities where green areas are threatened by urbanisation (Dallimer et al., 2011).

There are various evidence that areal size of green space near residential area is clearly correlated with physical activity (Bancroft et al., 2015; Paquet et al., 2013) among individuals with low stress levels (Fan et al., 2011), mental health (Gascon et al., 2015; Van den Berg et al., 2015) happiness, and general health (Maas et al., 2006; Verheij et al., 2008). The areal size of green space also has a positive influence on Ioneliness, social support, especially for children, the elderly and individuals with low level of economic status (Maas et al., 2009). There is a positive link between how often the green areas are visited, how much time is spent and the healing/decrease of stress and depression symptoms (Bedimo-Rung et al., 2005).

It is determined that there was a direct relationship with the green area in terms of quality of life and health (Grahn \& Stigsdotter, 2003; Nielsen \& Hansen, 2007; Stigsdotter et al., 2010). People living in the green area more than 1 kilometer closeness use open and green areas to do exercises less than the individuals living in the green area less than 300 meters (Toftager et al., 2011). It is determined that the individuals who have accessibility to green areas within a radius of 1-3 kilometers feel healthier compared to individuals living far away from green areas (Maas et al., 2006; Verheij et al., 2008). Spatial planning regulation states that urban open and green spaces such as playgrounds, sports areas, and urban parks should be planned within the service area of 500 meters, which is an accessible unit for pedestrians (Çevre ve Şehircilik Bakanlığından, 2014).

\%92 of the total population lives in urban areas according to the Turkish Statistical Institution data of 2018. Therefore, urban areas have a dense population which lead destructive pressure on urban green areas throughout the cities. This study aims to determine the socio-psychological effects of the functions and areal size of open green areas in Kirklareli, and to discuss the current status after the spatial analysis. In other words, the functional uses of the green areas and their spatial qualification were measured in Kırklareli. In the considerations of urban open and green areas, although the open and green area standard in the current zoning legislation green area per capita should be $10 \mathrm{~m}^{2}$, it was calculated in the present settlement areas in Kirklareli are less than $10 \mathrm{~m}^{2}$ and the green areas are not sufficient and qualified in terms of size and reinforcement. In this context, the aim of this study is to analyze the possible psychosocial consequences and to develop socio-spatial approaches.

In this context, the following correlations were examined;

- the proximity and the visiting time in the green area

- the frequency of green space usage and mood

- satisfaction of size of green area and the frequency of green area usage and visiting time

The following hypotheses were tested.

- The frequency of use and spending time rises as the areal size of the green area increases

- Emotionally positive feelings rise as the time spending increases

User profiles and needs of these urban green areas were defined by the survey study. Spatial analyses were conducted and spatial suggestions were developed to increase the use of green areas in the city center by considering user satisfaction and needs.

\section{Study Area}

Kirklareli Province is located in transition area of the southern Thrace Region of Turkey. The province has borders with Bulgaria to the north, Black Sea to the east, Istanbul to the southeast, Tekirdag to the south and Edirne to the west (Figure 1). It has a land area of $6550 \mathrm{~km}^{2}$ with an altitude of 203 meters above the sea level, a continental climate system and a total population of 351684 (TURKSTAT, 2016). Kirklareli city center, which is chosen as the study area, is located in the central part of Kirklareli province between $41^{\circ} 50$ 'North Latitudes and 27 - 20' East Longitude (Figure 1). The amount of build up area in 2018 is about 868 hectares. 


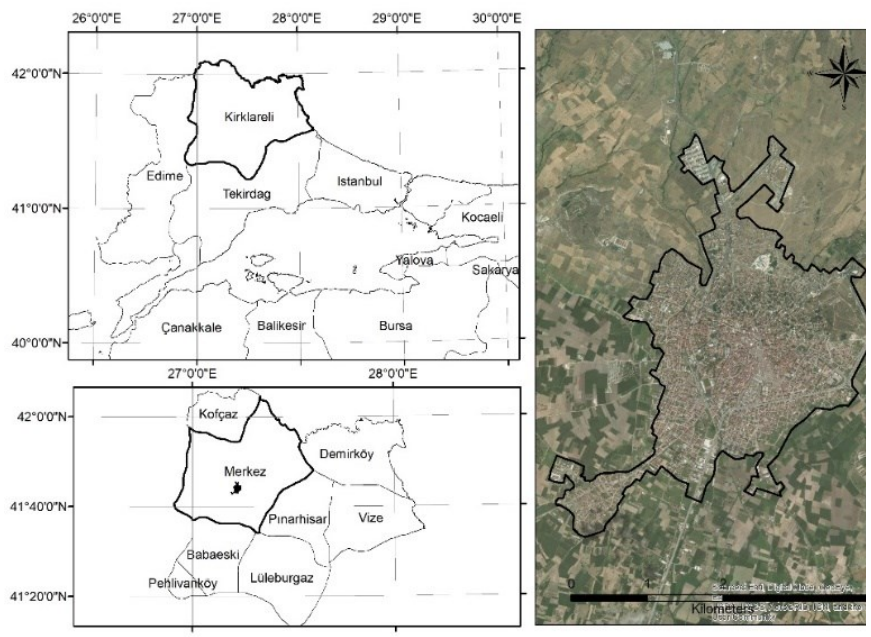

Figure 1. Location Map of Study Area.

Kirklareli Central District has a populated by 79093 people according to 2018 census data. The population of the central district has been growing steadily since 1965 (Figure 2).

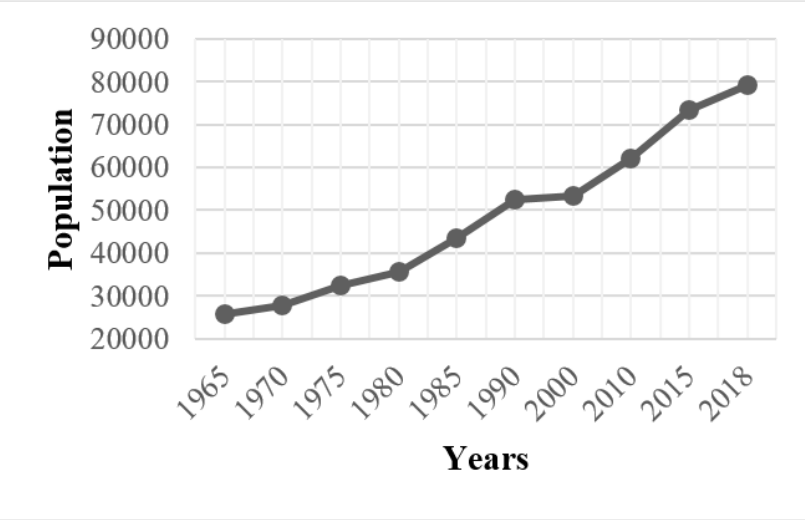

Figure 2. Population Growth by Years.

Total open and green areas were determined as 64.705 hectares within the built-up areas in Kirklareli city center of 2018 . The distribution of these areas in urban space is shown in Figures 3 and 4. Urban green and open areas compromised; the city's parks, squares, district sports areas, children's playgrounds and active open and green areas available to public use as specified in the spatial plans production regulation. The amount of open and green areas per capita was calculated as 0.8 $\mathrm{m}^{2}$. In this respect, it is seen that open and green areas per capita are $10 \mathrm{~m}^{2}$ which is specified in the same regulation.

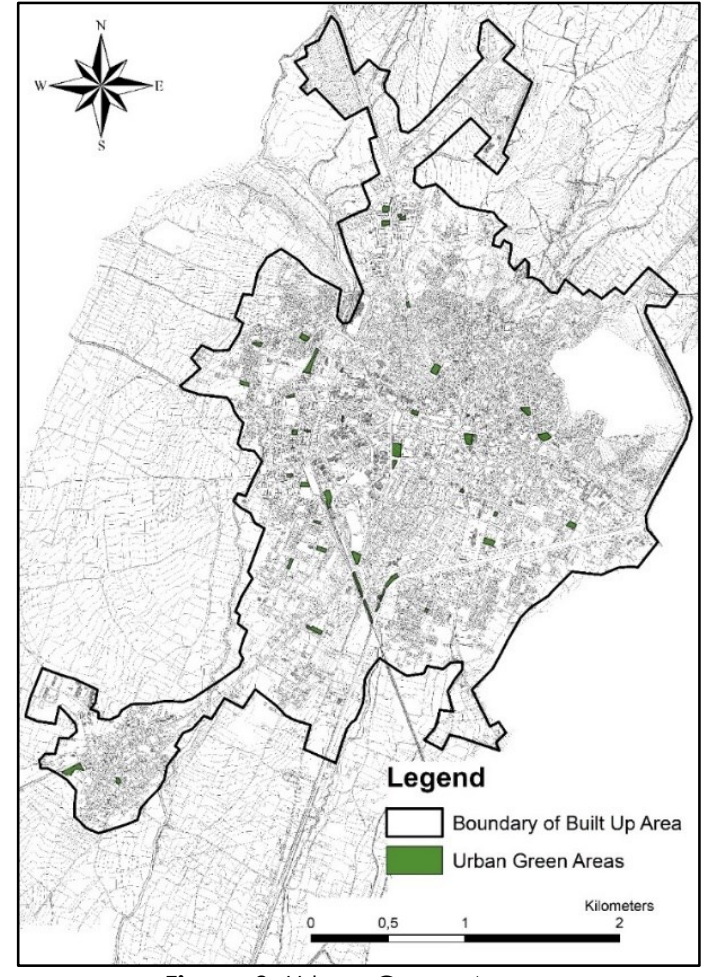

Figure 3. Urban Green Areas.

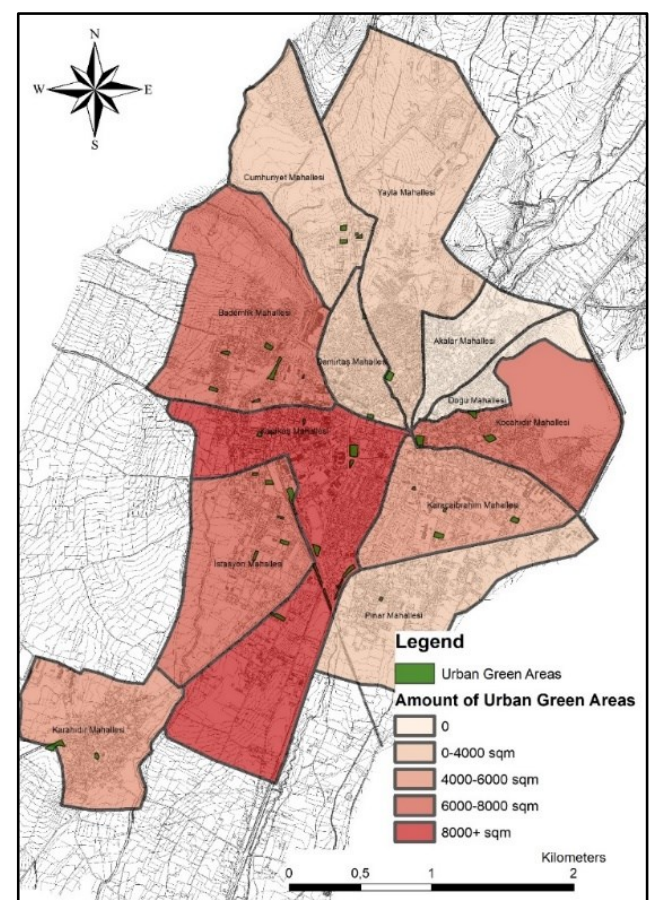

Figure 4. Amount of Urban Green Areas by Neigbourhood.

\section{Method}

The study consists of three sections; literature study, survey application and spatial analysis (Figure 5). In the conceptual framework of the study, the literature has been extensively investigated. As a result of this study, survey questions were prepared. Frequency, crosstab and Pearson Correlation analyses were applied to the survey questions. The flowchart of the study is shown below. 


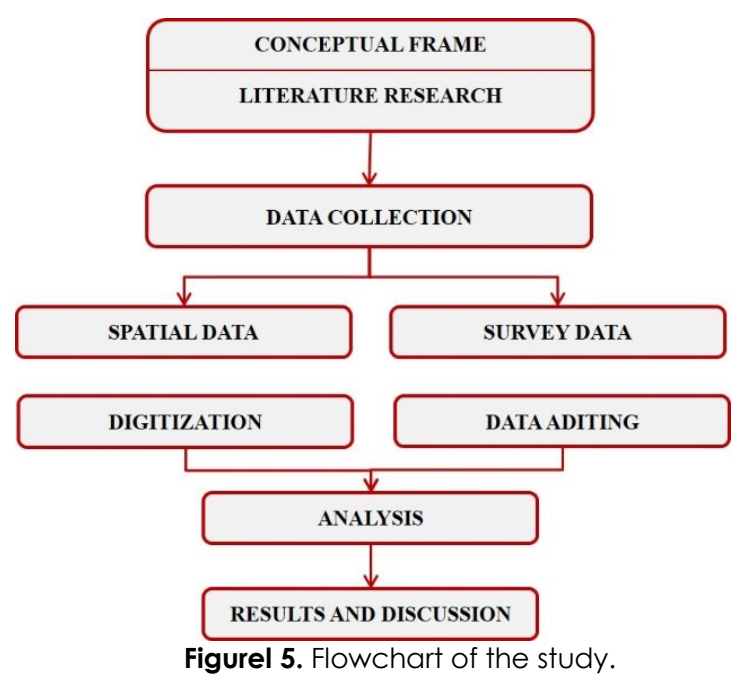

\section{1 Survey Application}

A survey was conducted to define the sociopsychological effects of urban green areas and user satisfaction. The population of Kirklareli city center is 77226 in 2017 based on Turkey Statistical Institute (TSI) Address Based Population Registration System Data (ABPRS). Accordingly, the distribution of population and number of surveys by neighborhoods is as follows (Table 1). A total of 770 surveys were applied in $4 \%$ sample size and $95 \%$ confidence level (Table 1, App. 1). The number of surveys to be conducted in neighborhoods was determined in proportion of population.

Table 1: Kırklareli City Center Neighborhood Population and Number of Surveys Applied in the Scope of the Study.

\begin{tabular}{|c|c|c|c|c|}
\hline \# & Neighbourhood & 2017 - Population Data & Number of Surveys & $\%$ \\
\hline 1 & Akalar & 3802 & 36 & 5 \\
\hline 2 & Bademlik & 6987 & 66 & 9 \\
\hline 3 & Cumhuriyet & 3539 & 35 & 5 \\
\hline 4 & Demirtaș & 3589 & 36 & 5 \\
\hline 5 & Doğu & 1292 & 18 & 2 \\
\hline 6 & İstasyon & 10111 & 98 & 13 \\
\hline 7 & Karacaibrahim & 12151 & 118 & 15 \\
\hline 8 & Karahıdır & 2278 & 18 & 2 \\
\hline 9 & Karakaș & 16510 & 185 & 24 \\
\hline 10 & Kocahıdır & 4762 & 46 & 6 \\
\hline 11 & Pinar & 5988 & 57 & 7 \\
\hline 12 & Yayla & 6217 & 57 & 7 \\
\hline & Total & 77226 & 770 & 100 \\
\hline
\end{tabular}

The highest and lowest survey percentages in the neighborhoods are Karakas with $24 \%$ of surveys, Karacaibrahim with $15 \%$ of surveys and Dogu and Karahidir with 2\% (Figure 6).

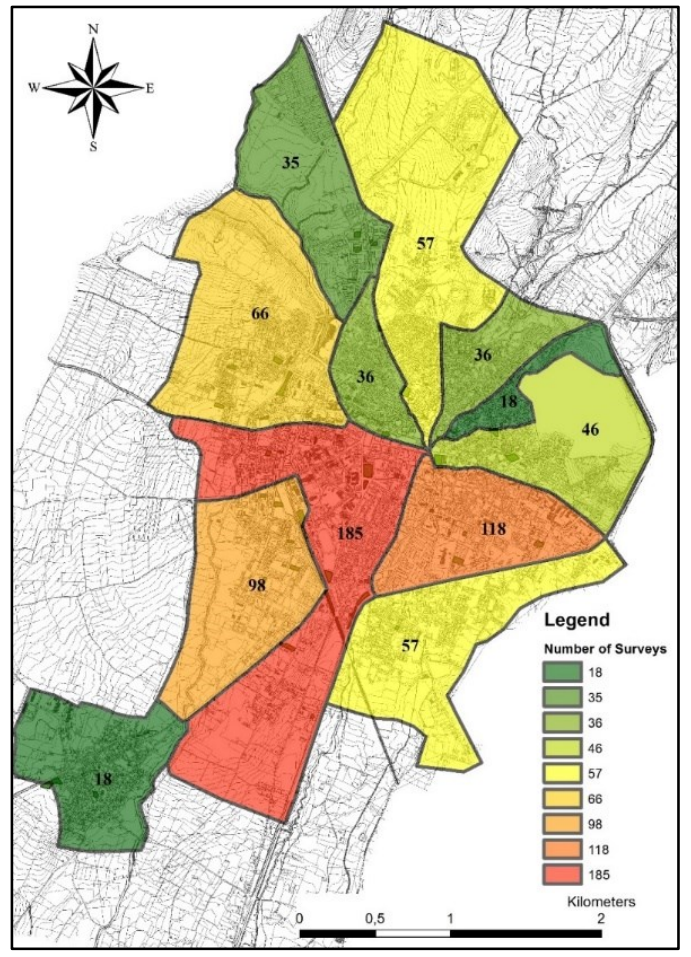

Figure 6. Number of Surveys per Neigbourhood.

The questions were prepared within the scope of the study were grouped into three main categories, in accordance with the literature review presented in the previous chapters. In the first category, questions were intended for evaluating users' profile. In the second category, questions were inquired about the duration of the existing park use, the purposes of use, the demands for close proximity to the parks and the factors affecting the positive/negative effects of the park use. In the third category, questions comprised health problems and emotions. The questions in the survey were generally arranged on a closed-ended and triple Likert scale. According to the answers given to the survey about health problems, participants with mental disorders were the main focus group of the study. The other participants were evaluated as control group.

The responses of the main group and the control group were evaluated in frequency and Pearson correlation analysis. Pearson Correlation analysis is a method of statistical evaluation used to examine the strength of a relationship between two, numerically measured, continuous variables. Pearson Product Moment correlation coefficient (abbreviated as $p$ in text) is the measurement of correlation and ranges (depending on the correlation) between +1 and $-1 .+1$ indicates the strongest positive correlation possible, and -1 indicates the strongest negative correlation possible (for the correlation coefficients between 0.00 and 0.25 means "too weak", the value between 0.26 and 0.49 means "weak", the value between 0.50 and 0.69 means "medium", between 0.70 and 0.89 the value means "high" and the 
value between 0,90 and 1,00 means "too high"). But only correlations that are significant at sigf < 0.05 or 0.01 should be considered (abbreviated as sigf in text) (Zaid, 2015)

\subsection{Spatial Analysis}

In the study, GIS and Remote Sensing technologies were used for spatial representation of green areas. Aerial photographs have a significant place in urban planning and are an important tool for meeting the changing economic, social and recreational needs of the society and for monitoring urban development. In order to get fast and accurate results in physical planning studies, it is necessary to use aerial photographs frequently. Therefore, as a quick method and providing reliable information, aerial photographs lead to interpretations for the future in various disciplines.

In this context, satellite images of 2015, obtained from the General Directorate of Mapping, were rectified according to the relevant external orientation parameters and made available for operation (Fig. 7). These maps were digitized for analyzing green areas distribution in the city. As a result of this qualitative and qualitative inquiries made about the use of urban green spaces and related spatial formation processes. Survey data were entered into the GIS environment and spatial representations were made.

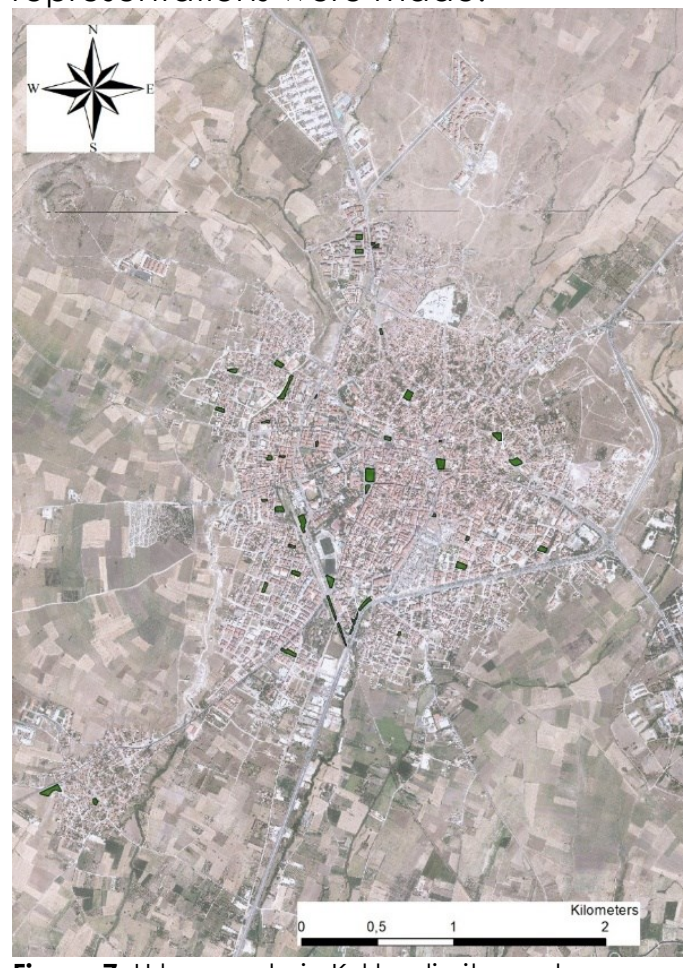

Figure 7. Urban parks in Kırklareli city center

\section{Results and Reviews}

Survey undercovered the current mood of the users, the mood in the park and the present health problems were determined. 196 people responded positively to the question of whether they had a health problem (See App-1, Question no: 36) (Table 2, Figure 8).
Table 2. Frequency Analysis of Survey

\begin{tabular}{|l|l|l|}
\hline \multirow{2}{*}{ Disease } & Frequency & \multirow{2}{*}{ Ratio (\%) } \\
\cline { 2 - 3 } & & \\
\hline Tension & 6 & 3 \\
\hline Respiratory & 57 & 29 \\
\hline Psychological & $\mathbf{3 1}$ & $\mathbf{1 6}$ \\
\hline Orthopedic & 51 & 26 \\
\hline Internal & 36 & 18 \\
\hline Others & 15 & 8 \\
\hline Total & $\mathbf{1 9 6}$ & $\mathbf{1 0 0}$ \\
\hline
\end{tabular}

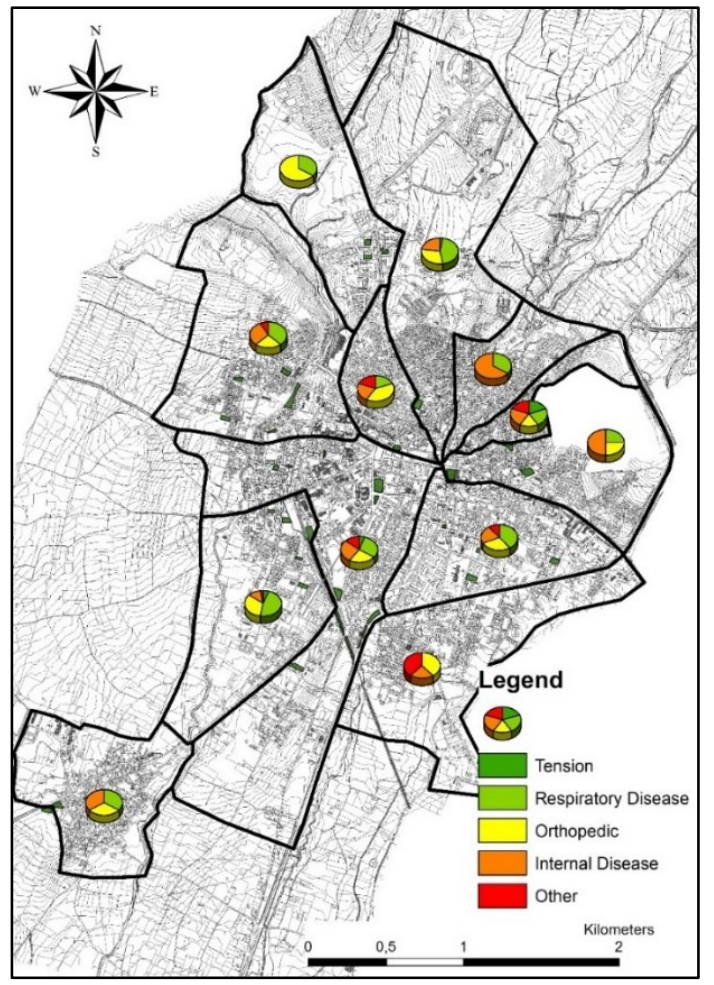

Figure 8. Disease reates by Neigbourhood

According to the survey data, users (31 persons) who stated that they had psychological disorder were identified as the main group to determine the user profile, user satisfaction and sociopsychological effects of the parks and the other users defined as the control group (739 persons). In the following sections, the results will be reported in detail in the frequency tables, cross-tables and correlation evaluations.

In the study, user satisfaction and sociopsychological parameters, frequency analysis were obtained and correlation tests were applied to measure the relationship strength between the factors affecting the user satisfaction and sociopsychological change. (App-1). According to this; In terms of user profile;

- The main and the control group is between the ages of 18-64 and has the education at the secondary and higher 
education level. The mean age of main group is lower than the control group.

In terms of user satisfaction;

- The main group predominantly lives in Karacaibrahim (25,8\%), Karakas $(22,6 \%)$ and Yayla $(19,6 \%)$ Neighborhoods.

- The main group can access the urban parks in the city by 5-10 minutes walking time. In the correlation test, there is a high positive relationship between the distance to the nearest green area and the time spending in the park (sigf: 0.000, p: 0.683).

- In the control group, it is seen that this distance is up to 15 minutes. In the correlation test, there is a positive relationship between the proximity to the nearest green area and the time spending in the park (sigf: 0.000, p: 0.577).

- There is a negative low-level relationship (sigf: 0.000, p: -0.275) among the responses given that distance to the nearest green area or accessibility are positively impacted on park use.

- The intended use of parks for the main group is limited to recreational activities. On the other hand, it was seen that there was a multilayered use in recreational, social and sports activities for the control group. The main explanations for the usage of urban open and green areas are social activity in the Karahıdır neighborhood and recreation in other neighborhoods. The proximity of the parks is among the last reasons for usage (Figure 9).

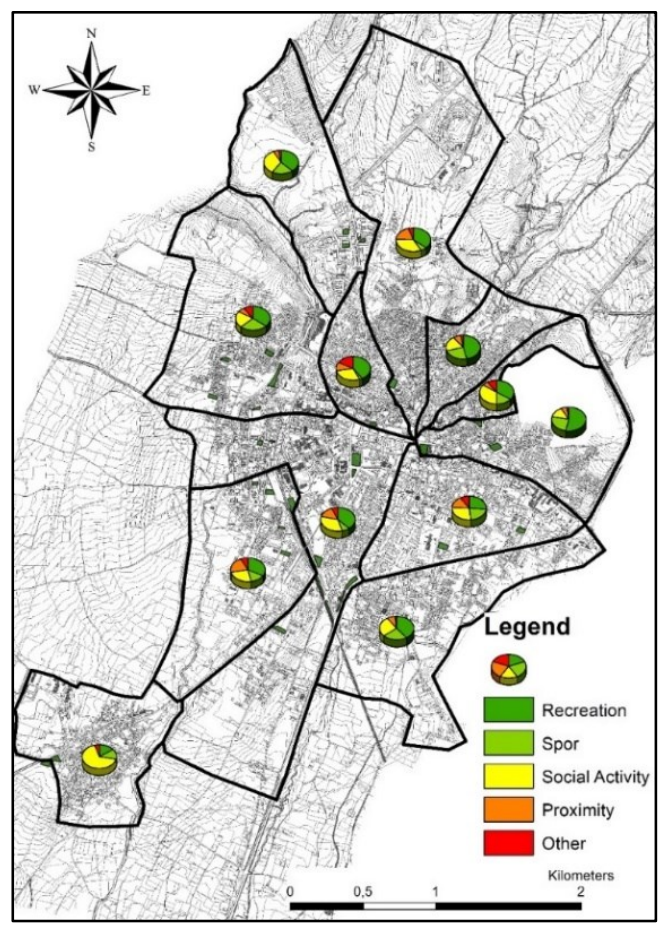

Figure 9. Urban Green Areas Usage.
- The usage frequency of urban open and green areas becomes more prominent once a week and more than once a week in all neighborhoods of the city. Daily park visiting is quite low throughout the city (Figure 10-11).

- The main group spends time in parks once a month or several times a week. However, control group visits parks several times a week. Similarly, the main group usually uses parks for less than 15 minutes, while the control group spends 15-30 minutes. In the correlation test, it is seen that the main group have a positive relationship between visiting time in the park and the accessibility, which is negatively affected by the park use (sigf: 0.027, p: -0.411). In the control group, there is a negative low-level relationship (sigf: 0.000, $\mathrm{p}$ : -0.284$)$ between the time spending in the park and the positive effect of accessibility to the parks.

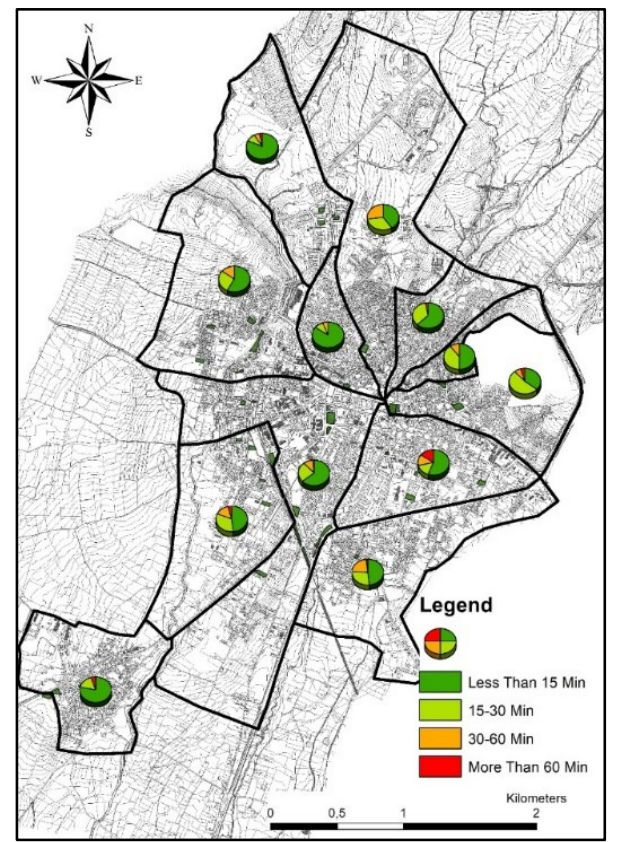

Figure 10. Duration of Urban Green Space Usage. 


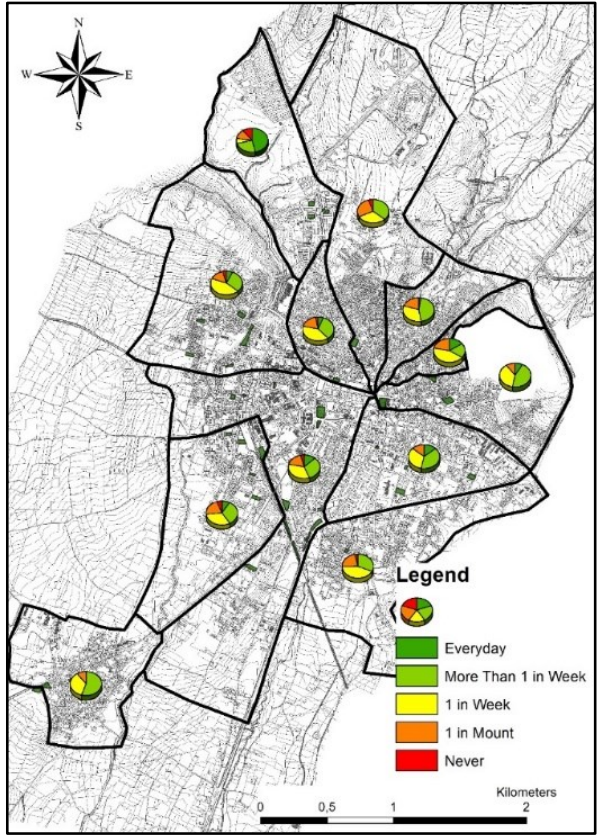

Figure 11. Urban Green Space Usage. parks, the main group differently consider lighting and insecurity which negatively affect the use of the parks. In the correlation test, it is seen that there is a high level of negative relationship (sigf: $0.000, p$ : -0.688 ) between the time spent in the park and the lack of night lighting. In the control group, the changes in the user profile of the evening are seen as the main criterion.

- When the cross-examination table (Table 3) was observed for the change between the current feeling and feeling in the park;

- In both groups, the users, who stated that they are depressed, tired and stressed in the last period, specified that they are happy, calm and peaceful in the park. In addition, the correlation test was performed for the main group, there was a positive, medium level relationship (sigf: $0.02, \mathrm{p}: 0.410$ ) between feeling in the park and landscape elements that positively affect the use of parking.

- Both groups choose the same equipment such as buffet and food and beverage units which positively affect the use of the

Table 2: Cross-Table in Main Group and Control Group for Current Feelings and Feelings in the Park.

\begin{tabular}{|c|c|c|c|c|c|c|c|}
\hline \multicolumn{8}{|c|}{ Main group } \\
\hline \multirow{2}{*}{ Mood } & \multicolumn{6}{|c|}{ Feeling In The Park } & \multirow{2}{*}{ Total } \\
\hline & Energetic & Tired & Happy & Depressed & Calm and Peaceful & Stressed & \\
\hline Energetic & 1 & 0 & 1 & 0 & 0 & 0 & 2 \\
\hline Tired & 1 & 1 & 1 & 1 & 5 & 0 & 9 \\
\hline Happy & 1 & 0 & 1 & 0 & 0 & 0 & 2 \\
\hline Depressed & 0 & 1 & 3 & 1 & 3 & 0 & 8 \\
\hline $\begin{array}{c}\text { Calm and } \\
\text { Peaceful }\end{array}$ & 0 & 0 & 1 & 1 & 2 & 0 & 4 \\
\hline Stressed & 1 & 0 & 0 & 0 & 4 & 1 & 6 \\
\hline Total & 4 & 2 & 7 & 3 & 14 & 1 & 31 \\
\hline \multicolumn{8}{|c|}{ Control group } \\
\hline \multirow{2}{*}{ Mood } & \multicolumn{6}{|c|}{ Feeling In The Park } & \multirow{2}{*}{ Total } \\
\hline & Energetic & Tired & Happy & Depressed & Calm and Peaceful & Stressed & \\
\hline Energetic & 54 & 4 & 21 & 4 & 56 & 5 & 144 \\
\hline Tired & 38 & 13 & 33 & 11 & 107 & 1 & 203 \\
\hline Нарру & 26 & 10 & 38 & 5 & 64 & 3 & 146 \\
\hline Depressed & 6 & 4 & 12 & 8 & 25 & 5 & 60 \\
\hline $\begin{array}{c}\text { Calm and } \\
\text { Peaceful }\end{array}$ & 18 & 5 & 25 & 8 & 52 & 6 & 114 \\
\hline Stressed & 8 & 3 & 7 & 7 & 28 & 6 & 59 \\
\hline Total & 150 & 39 & 136 & 43 & 332 & 26 & 726 \\
\hline
\end{tabular}

\section{Conclusion}

One of the main parameters of equality is accessibility to open green spaces that bring healthier communities. In other words, every inhabitant of a city has equal rights to utilize green space and to live a healthy life. Maintaining community green spaces enable health benefits for inhabitants such as resting, relieving stress, and other psychological effects that also decrease environmental and health inequalities by 
supplying them equal opportunities to use and benefit from green spaces, such as preserving from air pollution and noise. Many studies have proved relations between green areas close to residential areas and health profits affirming that spending time in green space can affect health benefits regardless of the level of physical activity.

Planning, designing and managing open green spaces or network play superior roles to provide vital new chances for societies. Our study aimed to expose the correlations between the designing, planning, accessibility, mobility and well-being due to the open green space organization in Kırklareli. The study involves three parts; literature study, survey application and spatial analysis. Surveys signified that green space and health has a positive relationship and pointed out that green space affected human mental health and stressreduction.

According to the survey and spatial analysis results, the green area per capita was calculated as 0,8 $\mathrm{m}^{2}$ which is very low due to the planning zone regulation. On the other hand, according to the survey results, parks have a positive psychological effect on the urban users and parks could only offer recreational aim for users with mental disorders. Although all users spend a long time in parks and visit them frequently. There are common negative evaluations such as change of user profile at nights, lack of lighting, noise and pollution. In this respect, the literature framework of the study is constant with the presented information. In addition, the number and size of parks should be increased and spatial quality should be improved in order to improve urban health.

In this regard, although the parks provide supportive results for the users to have a psychologically positive effect on the users; it is possible to say that parks of Kirklareli have a simple usage characteristic especially for users with psychological problems and do not satisfy them for socialization and social activities. Despite the limited use of parks in terms of the duration and type of usage for users with mental disorders, it is seen that the factors such as accessibility, lighting and landscaping elements related to the parks are more sensitive than the control group and the correlation between those factors is medium and high level. In the control group, there is no similar sensitivity level and the relations are generally low level. Therefore, it is possible to say that the design interventions in parks can influence the users with psychological disorders in terms of sociopsychological aspects and usage profile.

\section{Acknowledgement}

This article supported by Kirklareli University as coordinator of Scientific Research Projects.

\section{Conflict of interests}

The authors declare no conflict of interest.

\section{References}

Akpinar, A. (2014). Kullanıcıların kentsel yeşil yolları kullanım sebepleri, algıları ve tercihlerinin AydınKoşuyolu örneğinde incelenmesi [Investigation of the reasons, perceptions and preferences of users for urban green roads in Aydın / Koşuyolu case.]. Istanbul Üniversitesi Orman Fakültesi Dergisi, 64(2), 41-55. https://doi.org/10.17099/jffiu.31281

Alcock, I., White, M. P., Wheeler, B. W., Fleming, L. E., \& Depledge, M. H. (2014). Longitudinal effects on mental health of moving to greener and less green urban areas. Environmental Science \& Technology, 48(2), $1247-1255$ https://doi.org/10.1021/es403688w

Angel MartÍNez-GonzÁLez, M., Javier Varo, J., Luis Santos, J., De Irala, J., Gibney, M., Kearney, J., \& Alfredo MartÍNez, J. (2001). Prevalence of physical activity during leisure time in the European Union. Medicine \& Science in Sports \& Exercise, 33(7). https://doi.org/10.1097/00005768-20010700000011

Aydemir, S. (2004). Kentsel Açık ve Yeşil Alanlar "Rekreasyon" Kentsel Alanların Planlanması ve Tasarımı [Urban Open and Green Areas-recreation. Planning and Design of Urban Areas]. Akademi Kitabevi, Trabzon, 285-337.

Bancroft, C., Joshi, S., Rundle, A., Hutson, M., Chong, C., Weiss, C. C., Genkinger, J., Neckerman, K., \& Lovasi, G. (2015). Association of proximity and density of parks and objectively measured physical activity in the United States: A systematic review. Social Science \& Medicine, 138, 22-30. https:/doi.org/10.1016/j.socscimed.2015.05.034

Bedimo-Rung, A. L., Mowen, A. J., \& Cohen, D. A. (2005). The significance of parks to physical activity and public health: A conceptual model. American Journal of Preventive Medicine, 28(2, Supplement 2), $159-168$. https:/doi.org/10.1016/j.amepre.2004.10.024

Bratman, G. N., Hamilton, J. P., Hahn, K. S., Daily, G. C., \& Gross, J. J. (2015). Nature experience reduces rumination and subgenual prefrontal cortex activation. Proceedings of the National Academy of Sciences, 112(28), 8567-8572. https://doi.org/10.1073/pnas.1510459112

Çevre ve Şehircilik Bakanlığından. (2014). Mekansal Planlar Yapım Yönetmeliği [Spatial Plans Construction Regulation] (Regulation No: 29030). 
https://www.resmigazete.gov.tr/eskiler/2014/06/20 140614-2.htm

Çevre ve Şehircilik Bakanlığından. (2017). Planlı Alanlar Imar Yönetmeliği [Planned Areas Zoning Regulation] (Regulation No: 30113). https://www.resmigazete.gov.tr/eskiler/2017/07/20 170703-8.htm

Cicea, C., \& PÎRlogea, C. (2011). GREEN SPACES AND PUBLIC HEALTH IN URBAN AREAS. Theoretical and Empirical Researches in Urban Management, 6(1), 83-92. http://www.jstor.org/stable/24873277

Cohen, D. A., McKenzie, T. L., Sehgal, A., Williamson, S., Golinelli, D., \& Lurie, N. (2007). Contribution of public parks to physical activity. American journal of public health, 97(3), 509-514. https://doi.org/10.2105/AJPH.2005.072447

Dallimer, M., Tang, Z., Bibby, P., Brindley, P., Gaston, K., \& Davies, Z. (2011). Temporal changes in greenspace in a highly urbanised region. Biology letters, 7 763-766. https://doi.org/10.1098/rsbl.2011.0025

Ersoy, M. (2015). Kentsel Planlamada Standartlar [Standards in Urban Planning]. Ninova Yayınlarl: Istanbul.

Fan, Y., Das, K. V., \& Chen, Q. (2011). Neighborhood green, social support, physical activity, and stress: Assessing the cumulative impact. Health \& Place, 17(6), 1202-1211. https:/doi.org/10.1016/j.healthplace.2011.08.008

Fuller, R. A., \& Gaston, K. J. (2009). The scaling of green space coverage in European cities. Biology letters, $5(3)$

$352-355$. https://doi.org/10.1098/rsb1.2009.0010

Gascon, M., Triguero-Mas, M., Martínez, D., Dadvand, P., Forns, J., Plasència, A., \& Nieuwenhuijsen, M. J. (2015). Mental Health Benefits of Long-Term Exposure to Residential Green and Blue Spaces: A Systematic Review. International Journal of Environmental Research and Public Health, 12(4). https://doi.org/10.3390/ijerph120404354

Grahn, P., \& Stigsdotter, U. A. (2003). Landscape planning and stress. Urban Forestry \& Urban Greening, 2(1), 1-18. https:/doi.org/10.1078/1618-8667-00019

Honold, J., Lakes, T., Beyer, R., \& van der Meer, E. (2015). Restoration in Urban Spaces: Nature Views From Home, Greenways, and Public Parks. Environment and Behavior, 48(6), 796-825. https://doi.org/10.1177/0013916514568556

Huynh, Q., Craig, W., Janssen, I., \& Pickett, W. (2013). Exposure to public natural space as a protective factor for emotional well-being among young people in Canada. BMC Public Health, 13(1), 407. https://doi.org/10.1186/1471-2458-13-407
Kaczynski, A. T., Potwarka, L. R., \& Saelens, B. E. (2008). Association of park size, distance, and features with physical activity in neighborhood parks. American journal of public health, 98(8), 1451-1456. https://doi.org/10.2105/AJPH.2007.129064

Kaplan, R. (2001). The Nature of the View from Home: Psychological Benefits. Environment and Behavior, 33(4), 507-542. https://doi.org/10.1177/00139160121973115

Koohsari, M. J., Mavoa, S., Villanueva, K., Sugiyama, T., Badland, H., Kaczynski, A. T., Owen, N., \& GilesCorti, B. (2015). Public open space, physical activity, urban design and public health: Concepts, methods and research agenda. Health \& Place, 33, 75-82.

https:/doi.org/10.1016/j.healthplace.2015.02.009

Kremer, P., Hamstead, Z., Haase, D., McPhearson, T., Frantzeskaki, N., Andersson, E., Kabisch, N., Larondelle, N., Rall, E. L., \& Voigt, A. (2016). Key insights for the future of urban ecosystem services research. Ecology and Society, 21(2). https://doi.org/10.5751/ES-08445-210229

Lee, A. C. K., \& Maheswaran, R. (2011). The health benefits of urban green spaces: a review of the evidence. Journal of Public Health, 33(2), 212-222. https://doi.org/10.1093/pubmed/fdq068

Maas, J., Spreeuwenberg, P., van Winsum-Westra, M., Verheij, R. A., Vries, S., \& Groenewegen, P. P. (2009). Is Green Space in the Living Environment Associated with People's Feelings of Social Safety? Environment and Planning A: Economy and Space, 41(7), 1763-1777. https://doi.org/10.1068/a4196

Maas, J., Verheij, R. A., Groenewegen, P. P., de Vries, S., \& Spreeuwenberg, P. (2006). Green space, urbanity, and health: how strong is the relation? Journal of Epidemiology and Community Health, 60(7), 587. https://doi.org/10.1136/jech.2005.043125

Nielsen, T. S., \& Hansen, K. B. (2007). Do green areas affect health? Results from a Danish survey on the use of green areas and health indicators. Health \& Place, 13(4), 839-850. https:/doi.org/10.1016/j.healthplace.2007.02.001

Oktay, D. (1998). Green spaces and the ecological quality of housing: The case of Cypriot settlements. Ekistics, 65(391/392/393), 283-291. http://www.jstor.org/stable/43623310

Paquet, C., Orschulok, T. P., Coffee, N. T., Howard, N. J., Hugo, G., Taylor, A. W., Adams, R. J., \& Daniel, M. (2013). Are accessibility and characteristics of public open spaces associated with a better cardiometabolic health? Landscape and Urban Planning, 118, 70-78. https:/doi.org/10.1016/j.landurbplan.2012.11.011 
Roberts, H., Sadler, J., \& Chapman, L. (2018). The value of Twitter data for determining the emotional responses of people to urban green spaces: A case study and critical evaluation. Urban Studies, 56(4), 818-835.

https://doi.org/10.1177/0042098017748544

Schipperijn, J., Bentsen, P., Troelsen, J., Toftager, M., \& Stigsdotter, U. K. (2013). Associations between physical activity and characteristics of urban green space. Urban Forestry \& Urban Greening, 12(1), 109-116. https:/doi.org/10.1016/j.ufug.2012.12.002

Shishegar, N. (2014). The Impacts of Green Areas on Mitigating Urban Heat Island Effect: A Review (Published in 2014). The International Journal of Environmental Sustainability, 9, 119-130. https://www.researchgate.net/publication/2712064 61_The_Impacts_of_Green_Areas_on_Mitigating Urban_Heat_Island_Effect_A_Review_Published_ in_2014

Soga, M., \& Gaston, K. J. (2016). Extinction of experience: the loss of human-nature interactions. Frontiers in Ecology and the Environment, 14(2), 94-101. https://doi.org/10.1002/fee.1225

Stigsdotter, U. K., Ekholm, O., Schipperijn, J., Toftager, M., Kamper-Jørgensen, F., \& Randrup, T. B. (2010). Health promoting outdoor environments Associations between green space, and health, health-related quality of life and stress based on a Danish national representative survey. Scandinavian Journal of Public Health, 38(4), 411 417. https://doi.org/10.1177/1403494810367468

Tamosiunas, A., Grazuleviciene, R., Luksiene, D., Dedele, A., Reklaitiene, R., Baceviciene, M., Vencloviene, J., Bernotiene, G., Radisauskas, R., Malinauskiene, V., Milinaviciene, E., Bobak, M., Peasey, A., \& Nieuwenhuijsen, M. J. (2014). Accessibility and use of urban green spaces, and cardiovascular health: findings from a Kaunas cohort study. Environmental Health, 13(1), 20. https://doi.org/10.1186/1476-069X-13-20

Toftager, M., Ekholm, O., Schipperijn, J., Stigsdotter, U., Bentsen, P., Grønbæk, M., Randrup, T. B., \& Kamper-Jørgensen, F. (2011). Distance to green space and physical activity: a Danish national representative survey. Journal of Physical Activity and Health, 8(6), 741-749. https://doi.org/10.1123/jpah.8.6.741

Van den Berg, M., Wendel-Vos, W., van Poppel, M., Kemper, H., van Mechelen, W., \& Maas, J. (2015). Health benefits of green spaces in the living environment: A systematic review of epidemiological studies. Urban Forestry \& Urban Greening, 14(4), 806-816. https:/doi.org/10.1016/j.ufug.2015.07.008
Verheij, R. A., Maas, J., \& Groenewegen, P. P. (2008). Urban-Rural Health Differences and the Availability of Green Space. European Urban and Regional Studies, 15(4), 307-316. https://doi.org/10.1177/0969776408095107

Villeneuve, P. J., Jerrett, M., G. Su, J., Burnett, R. T., Chen, H., Wheeler, A. J., \& Goldberg, M. S. (2012). A cohort study relating urban green space with mortality in Ontario, Canada. Environmental Research, 115, 51-58. https:/doi.org/10.1016/j.envres.2012.03.003

World Health Organization. (2018). Physical activity for health: more active people for a healthier world: draft global action plan on physical activity 20182030.

https://apps.who.int/gb/ebwha/pdf_files/WHA71/A 71_18-en.pdf

Zaid, M. A. (2015). Correlation and regression analysis. The Statistical, Economic and Social Research and Training Centre for Islamic Countries (SESRIC), Turkey.

https://www.oicstatcom.org/file/TEXTBOOKCORRELATION-AND-REGRESSIONANALYSIS-EGYPT-EN.pdf

Check for

Updates

How to Cite this Article:

Tok, E , Ağdaş, M.G., Özkök, M.K and Kuru, A. (2020). SocioPsychological Effects of Urban Green Areas: Case of Kirklareli City Center. Journal of Contemporary Urban Affairs, 4(1), 47-60. https://doi.org/10.25034/ijcua.2020.v4n1-5 
Appendix 1: Survey Frequency Analysis Table for Main and Control Group

\begin{tabular}{|c|c|c|c|c|c|}
\hline \multicolumn{3}{|c|}{ Survey evaluation by other users } & \multicolumn{3}{|c|}{$\begin{array}{l}\text { Survey evauation by users that answered the "do you have any } \\
\text { discomfort?" (see question 36) " as "psychological discomfort" }\end{array}$} \\
\hline \multicolumn{6}{|c|}{ I. User Profile } \\
\hline Age Groups & Frequency & Percent (\%) & Age Groups & Frequency & Percent (\%) \\
\hline Young (0-17) & 24 & 3.2 & Young (0-17) & 2 & 6.5 \\
\hline Adult (18-64) & 689 & 93.2 & Adult (18-64) & 28 & 90.3 \\
\hline Elderly (65+) & 26 & 3.5 & Elderly (65+) & 1 & 3.2 \\
\hline Total & 739 & 100.0 & Total & 31 & 100.0 \\
\hline \multicolumn{3}{|c|}{ Minimum Age: 12} & \multicolumn{3}{|c|}{ Minimum Age: 16} \\
\hline \multicolumn{3}{|c|}{ Maximum Age: 85} & \multicolumn{3}{|c|}{ Maximum Age: 67} \\
\hline \multicolumn{3}{|c|}{ Average Age: 32} & \multicolumn{3}{|c|}{ Average Age: 26} \\
\hline Gender & Frequency & Percent (\%) & Gender & Frequency & Percent (\%) \\
\hline Male & 429 & 58.1 & Male & 23 & 74.2 \\
\hline Female & 310 & 41.9 & Female & 8 & 25.8 \\
\hline Total & 739 & 100.0 & Total & 31 & 100.0 \\
\hline Education Status & Frequency & Percent (\%) & Education Status & Frequency & Percent (\%) \\
\hline Literate & 101 & 13.7 & Literate & 2 & 6.5 \\
\hline Illiterate & 25 & 3.4 & Elementary school & 7 & 22.6 \\
\hline Elementary school & 109 & 14.7 & Secondary school & 6 & 19.4 \\
\hline Secondary school & 206 & 27.9 & University & 16 & 51.6 \\
\hline University & 298 & 40.3 & Total & 31 & 100.0 \\
\hline Total & 739 & 100.0 & & & \\
\hline \multicolumn{6}{|c|}{ II. User Satisfaction } \\
\hline Walking Time To Nearest Park & Frequency & Percent $(\%)$ & Walking Time To Nearest Park & Frequency & Percent (\%) \\
\hline 5 minutes & 278 & 37.6 & 5 minutes & 10 & 32.3 \\
\hline 6-10 minutes & 178 & 24.1 & 6-10 minutes & 10 & 32.3 \\
\hline $11-15$ minutes & 125 & 16.9 & $11-15$ minutes & 4 & 12.9 \\
\hline 16-20 minutes & 86 & 11.6 & 16-20 minutes & 2 & 6.5 \\
\hline 20 minutes and more & 71 & 9.6 & 20 minutes and more & 5 & 16.1 \\
\hline Total & 739 & 100.0 & Total & 31 & 100.0 \\
\hline Purpose of Park Usage & Frequency & Percent (\%) & Purpose of Park Usage & Frequency & Percent (\%) \\
\hline Rekreation & 256 & 35.4 & Recreation & 17 & 54.8 \\
\hline Spor & 122 & 16.9 & Spor & 5 & 16.1 \\
\hline Social activities & 253 & 28.0 & Social activities & 3 & 9.7 \\
\hline Closeness to the place where they live & 88 & 12.2 & Closeness to the place where they live & 1 & 3.2 \\
\hline Socialization & 50 & 6.9 & Others & 5 & 16.1 \\
\hline Others & 5 & .7 & Total & 31 & 100.0 \\
\hline Total & 724 & 100.0 & & & \\
\hline Frequency of Park Usage & Frequency & Percent (\%) & Frequency of Park Usage & Frequency & Percent (\%) \\
\hline Never & 27 & 3.7 & Never & 1 & 3.2 \\
\hline Once in mount & 127 & 17.3 & Once in mount & 8 & 25.8 \\
\hline Once in week & 261 & 35.6 & Once in week & 7 & 22.6 \\
\hline More than one in week & 251 & 34.2 & More than one in week & 9 & 29.0 \\
\hline Everyday & 67 & 9.1 & Everyday & 6 & 19.4 \\
\hline Total & 733 & 100.0 & Total & 31 & 100.0 \\
\hline Spending Time in a Park & Frequency & Percent (\%) & Spending Time in a Park & Frequency & Percent (\%) \\
\hline 15 minutes and less & 396 & 57.6 & 15 minutes and less & 19 & 61.3 \\
\hline $15-30$ minutes & 176 & 25.6 & $15-30$ minutes & 6 & 19.4 \\
\hline 30-60 minutes & 87 & 12.6 & 30-60 minutes & 4 & 12.9 \\
\hline
\end{tabular}




\begin{tabular}{|l|l|l|l|l|l|}
60 minutes and more & 29 & 4.2 & 60 minutes and more & 2 \\
\hline Total & 688 & 100.0 & Total & 31 \\
\hline
\end{tabular}

II.I. Question 27. Do the following have a positive impact on the use of the nearby park / green area? (Prominent 3 answers)

\begin{tabular}{|c|c|c|c|c|c|}
\hline Urban Furniture & Frequency & Percent (\%) & Accesibility & Frequency & Percent (\%) \\
\hline Yes & 311 & 42.1 & Yes & 15 & 48.4 \\
\hline No & 428 & 57.9 & No & 16 & 51.6 \\
\hline Total & 739 & 100.0 & Total & 31 & 100.0 \\
\hline Facilities & Frequency & Percent (\%) & Urban Furniture & Frequency & Percent (\%) \\
\hline Yes & 309 & 41.8 & Yes & 12 & 38.7 \\
\hline No & 430 & 58.2 & No & 19 & 61.3 \\
\hline Total & 739 & 100.0 & Total & 31 & 100.0 \\
\hline Landscape Elements & Frequency & Percent (\%) & Landscape Elements & Frequency & Percent (\%) \\
\hline Yes & 253 & 34.2 & Yes & 8 & 25.8 \\
\hline No & 486 & 65.8 & No & 23 & 74.2 \\
\hline Total & 739 & 100.0 & Total & 31 & 100.0 \\
\hline
\end{tabular}

II.II. Question 28. Do the following have a negative impact on the use of the nearby park / green area? (Prominent 3 answers)

\begin{tabular}{|c|c|c|c|c|c|}
\hline Pollution & Frequency & Percent (\%) & Pollution & Frequency & Percent (\%) \\
\hline Yes & 384 & 52.0 & Yes & 13 & 41.9 \\
\hline No & 355 & 48.0 & No & 18 & 58.1 \\
\hline Total & 739 & 100.0 & Total & 31 & 100.0 \\
\hline Noise & Frequency & Percent (\%) & Noies & Frequency & Percent (\%) \\
\hline Yes & 347 & 47.0 & Yes & 10 & 32.3 \\
\hline No & 392 & 53.0 & No & 21 & 67.7 \\
\hline Total & 739 & 100.0 & Total & 31 & 100.0 \\
\hline User Profile Change for Night Time & Frequency & Percent (\%) & $\begin{array}{l}\text { Lack of Lighting in Evening / Insecurity } \\
\text { (two different answers at the same rate) }\end{array}$ & Frequency & Percent (\%) \\
\hline Yes & 241 & 32.6 & Yes & 9 & 29.0 \\
\hline No & 498 & 67.4 & No & 22 & 71.0 \\
\hline Total & 739 & 100.0 & Total & 31 & 100.0 \\
\hline
\end{tabular}


www.ijcua.com

This page is intentionally left blank. 